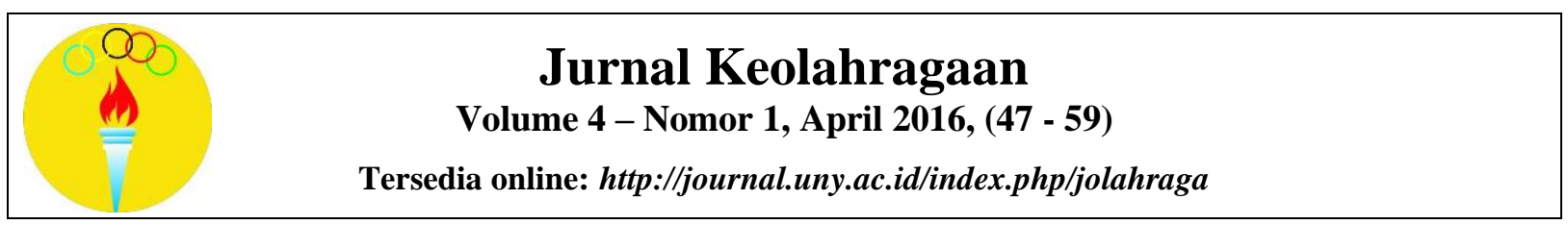

\title{
PENGARUH METODE UCHIKOMI DAN FLEXIBILITY TERHADAP HASIL BANTINGAN PADA PEJUDO DAERAH ISTIMEWA YOGYAKARTA
}

\author{
Suwarli \\ Program Studi Pendidikan Jasmani Kesehatan dan Rekreasi, FKIP Universitas Lampung, Jalan \\ Sumantri Brojonegoro No. 01, Lampung, Indonesia. \\ Korespondensi Penulis: Email: suwarli.alhidayah@gmail.com
}

\begin{abstract}
Abstrak
Penelitian bertujuan mengetahui: (1) perbedaan pengaruh antara metode uchikomi dengan menggunakan karet ban sepeda dan uchikomi jalan terhadap hasil bantingan judo, (2) perbedaan hasil bantingan antara pejudo yang memiliki flexibility tinggi dan flexibility rendah, dan (3) interaksi antara metode uchikomi dan flexibility terhadap hasil bantingan judo. Metode penelitian adalah eksperimen dengan rancangan faktorial $2 \times 2$. Populasi penelitian adalah pejudo D.I. Yogyakarta yang berjumlah 44 pejudo. Sampel penelitian ini 24 pejudo yang diambil dengan teknik Purposive Rondom Sampling. Data penelitian ini diperoleh melalui tes dan pengukuran. Instrumen penelitian adalah sit and reach dan Randori (dipertandingkan) selama tiga menit. Teknik analisis data menggunakan ANAVA. Hasil penelitian bahwa: (1) ada perbedaan pengaruh yang signifikan antara latihan uchikomi dengan menggunakan karet ban sepeda dan uchikomi jalan terhadap hasil bantingan judo, (2) ada perbedaan yang signifikan hasil bantingan judo antara pejudo yang memiliki flexibility tinggi dan flexibility rendah, dan (3) ada interaksi antara metode uchikomi dan flexibility terhadap hasil bantingan judo.
\end{abstract}

Kata Kunci: Metode latihan uchikomi, flexibility, judo, hasil bantingan judo.

\section{THE EFFECT OF UCHIKOMI METHOD AND FLEXIBILITY AGAINST DINGS RESULTS AMONG JUDOKA D.I YOGYAKARTA}

\begin{abstract}
Abstrack
This study aimed to determine: (1) the difference between the effect of uchikomi method using rubber tires and on the road uchikomi dings judo results, (2) the difference between the results dings among judoka which have high flexibility and low flexibility, and (3) the interaction between uchikomi method and flexibility of the dings results. This research is experimental with $2 \times 2$ factorial design. The population was judoka D.I. Yogyakarta, amounting to 44 judokas. The 24 samples were taken with random purposive sampling. All were data obtained through this study to test and measure the flexibility using the sit and reach test and the results of the Randori judo dings (contested) for three minutes. The data analysis technique used is the variant analysis ANOVA. The results of this study indicate that: (1) there is a significant difference between uchikomi exercises using a bicycle tire rubber and on the road uchikomi dings judo results, (2) there is a significant difference between the results of dings judo judoka which have high flexibility and low flexibility, and (3) there is an interaction between uchikomi method and flexibility against dings judo results.
\end{abstract}

Keywords: Uchikomi method exercise, flexibility, judo, judo slam result

How to Cite Item: Suwarli, S. (2016). Pengaruh metode uchikomi dan flexibility terhadap hasil bantingan pada pejudo Daerah Istimewa Yogyakarta. Jurnal Keolahragaan, 4(1), 47-59. doi:http://dx.doi.org/10.21831/jk.v4i1.8135

Permalink/DOI: http://dx.doi.org/10.21831/jk.v4i1.8135 


\section{PENDAHULUAN}

Sejalan dengan pepatah Romawi Kuno "Orandum Est ut sit Mens Sana In Corporesano" yang berarti di dalam tubuh yang sehat diharapkan juga terdapat jiwa yang sehat. Saat ini perkembangan dunia olahraga semakin hari semakin modern dan diikuti dengan kemajuan ilmu pengetahuan dan teknologi yang mempengaruhi perkembangan dan daya pikir insan olahraga sehingga diperlukan pemilihan metode-metode latihan yang tepat dan efektif untuk menunjang prestasi olahraga. Suatu hal yang tidak pernah lepas dari dunia olahraga yaitu adanya latihan, tanpa latihan tidak mungkin tercapai prestasi secara optimal. Di dalam berlatih atau bekerja, harus dilakukan secara berulang-ulang, dengan kian hari kian menambah jumlah beban latihan atau pekerjaannya sehingga tercapainya peningkatan dalam latihan.

Pengertian judo menurut Achmad (2013, p.2).adalah salah satu cabang olahraga beladiri yang berasal dari Jepang dan telah menjadi olahraga yang populer pada saat ini. Judo diciptakan oleh Prof Jigoro Kano atau Maha Guru Jigoro Kano pada tahun 1882 yang disebut juga Nippon Den Kodokan. Judo berasal dari teknik-teknik Jujitsu atau Yawara yang merupakan salah satu jenis Bujutsu (seni beladiri tradisional Jepang) yaitu perkelahian tangan kosong. Jujutsu berisikan teknik-teknik seperti membanting, memiting, mencekik, mematahkan, persendian, memutar, pukulan, dan menendang.

Menurut Kano (Inokuma \& Sato, 2001, p.10) bahwa bahwa judo memiliki arti sebagai berikut: "The word jujutsu and judo are eachwritten with two chinese characters the ju in both is the same and means gantleness or giving away the meaning of jutsu "art practice". and do means "principle or way". The way being as the concept of life it self jujutsu may be translated as "the gentle art judo as the way of gentleness" with the implication offirst giving way toultimately gain victory". Maksud dari pernyataan tersebut adalah kata jujutsu dan judo ditulis dalam dua karakter China. Arti $J u$ pada kedua kata tersebut sama dan berarti lemah lembut atau memberi jalan. Sedangkan jutsu berarti seni atau latihan dan do berarti prinsip atau cara. Cara yang menjadi pengertian dari hidup itu sendiri. Jujutsu boleh diterjemahkan dengan seni yang lemah lembut, judo berarti cara yang lemah lembut untuk membela diri.
Olahraga judo merupakan olahraga kompetitif yang memberikan kesempatan bagi atlet untuk menunjukkan prestasi dan pembinaan atlet, baik melalui latihan di klub-klub maupun perkumpulan lainnya. Kano (Inokuma \& Sato, 2001, p.20) menjelaskan bahwa: "it's aim is making the body strong, useful and healthy while building character through mental and moral discipline". Tujuan olahraga judo menurut Achmad (2013, p.15) menjelaskan bahwa: olahraga judo adalah untuk membina mental maupun fisik seseorang, berjiwa ksatria yang disesuaikan dengan arti daripada judo itu sendiri, yaitu $J u$ berarti kebenaran dan $D o$ berarti jalan. Jadi seorang pejudo haruslah berjalan pada garis yang benar sesuai dengan jiwa seorang ksatria. Sukadiyanto (2010, p.11) bahwa: "Tujuan serta sasaran utama dari latihan atau training adalah meningkatkan kemampuan, keterampilan, dan penampilan atlet dengan bimbingan pelatih".

Ada dua sebutan bagi orang yang sedang berlatih Judo yaitu Tori dan Uke. Tori adalah orang melakukan bantingan, sedangkan Uke adalah orang yang dibanting. Dalam olahraga judo juga dikenal berbagai macam teknik dasar seperti membanting, mengangkat, menarik, mendorong, mencekik atau mengunci persendian lawan. Selain itu perlu dikuasai teknikteknik jatuhan (ukemi) dan teknik menghilangkan keseimbangan lawan (kuzushi). Ada beberapa teknik bantingan dalam judo yang harus dipelajari oleh pejudo, teknik bantingan judo yaitu: (1) Te-Waza (teknik melempar atau membanting dengan tangan/lengan), (2) Koshi-Waza (teknik melempar atau membanting dengan panggul), (3) Ashi-Waza (teknik melempar atau membanting dengan kaki/paha), (4) SutemiWaza (teknik melempar atau membanting dengan menjatuhkan diri), (5) Yoko-Sutemi-Waza (teknik melempar atau membanting dengan sambil menjatuhkan diri ke samping). Blais, Trilles, \& Lacouture (2007, p.21) yakni: "Though you should be familiar with all kind of nage waza, you will find it to your advantage to discover the one or two that particularly seem to suit you and work on them until you have mastered them completely". Maksud pernyataan tersebut adalah bahwa para pejudo yang baik harus mengetahui semua teknik "nage waza" dan mengunggulkan satu atau dua teknik yang paling cocok baginya dan melakukan latihan sehingga benar-benar menguasainya. Karena itu seorang pejudo harus menguasai teknik andalan dengan sebaik mungkin. 
Menurut Elias (2000, p.17) Gokyo No Waza terdiri atas 5 kelompok bantingan yaitu: (1) rokkyu, (2) gokyu,(3) sankyu, (4) nikyu, (5) $i k k y u$. Masing-masing kelompok tersebut terdiri atas 8 teknik. Berikut adalah rincian dari pengklasifikasian Gokyo No Waza. (1) Dai Ikyyo (kelompok 1) yang terdiri atas teknik: bantingan dengan menggunakan kaki (Deashi Harai, Hiza uruma, Sasae Tsurikomi Ashi, Uki Goshi, Osoto Gari, O Goshi, Ouchi Gari), dan teknik bantingan dengan menggunakan tangan tangan (Seoi Nage), (2) Dai Nikyo (kelompok 2) yang terdiri atas teknik: bantingan dengan menggunakan kaki (Kosoto Gari, Kouchi Gari, Koshi Guruma, Uchi Mata), teknik bantingan dengan menggunakan pinggang (Tsurikomi Goshi, Okuriashi Harai), dan teknik bantingan dengan memutar badan (Tai Otoshi, Harai Goshi, (3) Sankyo (kelompok 3) yang terdiri atas teknik: bantingan dengan menggunakan kaki (Kosoto Gake, Tsuri Goshi), teknik bantingan dengan menggunakan pinggang (Yoko Otoshi. Ashi Guruma. Hane Goshi. Harai Tsurikomi Ashi), teknik bantingan berputar (Tomoe Nage, Kata Guruma). (4) Yonkyo (kelompok 4) yang terdiri atas teknik: Sumi Gaeshi, Tani Otoshi. Hane Makikomi, Sukui Nage. Utsuri Goshi, O Guruma, Soto Makikomi, Uki Otoshi, (5) Gokyo (kelompok 5) yang terdiri atas teknik: bantingan dengan menggunakan kaki (Osoto Guruma), teknik bantingan dengan menggunakan pinggang (Uki Waza), teknik bantingan berputar (Yoko Wakare, Yoko Guruma, Ushiro), teknik bantingan dengan menggunakan tangan (Goshi Ura Nage, Sumi Otoshi, Yoko Gake).

Dalam Judo terdapat pembagian teknik atau klasifikasi sesuai tingkatan yang akan di pelajari. Teknik-teknik yang akan dipelajari tesebut disesuaikan dengan tingkatan yang ada di dalam judo sendiri. Menurut Achmad (2013, p.22) bagi semua pejudo pemula warna sabuknya adalah putih. Berikut lebih rincinya:

Bagi remaja (berumur di bawah 16 tahun) adalah sebagai berikut: (1) Kyu-5 sabuk berwarna kuning. (2) Kyu-4 sabuk berwarna oranye. (3) $K y u-3$ sabuk berwarna hijau. (4) $K y u-2$ sabuk berwarna biru. (5) Kyu-1 sabuk berwarna coklat. Bagi taruna (Putra berumur 16-20 tahun dan putri 16-19 tahun) dan dewasa/senior adalah: (1) Kyu-5 sampai dengan kyu-4 sabuk berwarna biru. (2) $K y u-3$ sampai dengan kyu-1 sabuk berwarna coklat. (3) Dan-1 sampai dengan Dan-5 sabuk berwarna hitam. (4) Dan-6 sampai dengan Dan-8 sabuk berwarna merah putih/hitam. (5) Dan-9 sampai dengan Dan-10 sabuk berwarna merah atau hitam.

Biasanya untuk mengetahui tingkat seorang pejudo selain melihat warna sabuk adalah dengan adanya strip yang sesuai dengan warna sabuk pada ujung bawah level judogi, jumlah strip tersebut sesuai dengan tingkat judo. Berdasarkan teori tingkatan sabuk di atas dalam penelitian ini tidak semua pejudo bisa mengikuti program latihan yang akan diberikan melainkan hanya pejudo yang sudah mencapai kyu 3, hal ini karena persyaratan dalam kejuaraan para pejudo memiliki syarat mengikuti kejuaraan minimal kyu 3.

"Training is usually defined as systematic process of repetitive, progressive exercises, having the ultimate goal of improving athletic performance" (Bompa \& Haff, 2009, p.125). Artinya bahwa latihan biasanya didefinisikan sebagai suatu proses sistematis yang dilakukan secara berulang-ulang, progresif, dan mempunyai tujuan untuk meningkatkan penampilan fisik. "Latihan merupakan aktifitas olahraga yang sistematis dalam waktu yang lama, ditingkatkan secara progresif dan individual yang mengarah kepada ciri-ciri fungsi psikologis dan fisiologis manusia untuk mencapai sasaran yang ditentukan (Bompa \& Haff, 2009, p.10)". Selanjutnya Weinberg \& Gould (2007, p. 490) bependapat bahwa "Proses latihan adalah lebih banyak lebih baik, yang harus memulai tahapan awal, dan kemudian dilakukan secara berkelanjutan untuk bersaing di tingkat yang lebih tinggi". Sedangkan menurut Sukadiyanto (2010, p.7) latihan berasal dari kata bahasa Inggris yang dapat mengandung beberapa makna seperti: "practice, exercices, dan training". Pengertian latihan yang berasal dari kata practice adalah aktivitas untuk meningkatkan keterampilan (kemahiran) berolahraga dengan menggunakan berbagai peralatan sesuai dengan tujuan dan kebutuhan cabang olahraganya. Pengertian latihan yang berasal dari kata exercise adalah perangkat utama dalam proses latihan harian untuk meningkatkan kualitas fungsi sistem organ tubuh manusia, sehingga mempermudah olahragawan dalam penyempurnaan geraknya. Sedangkan Pengertian latihan yang berasal dari kata training adalah penerapan dari suatu perencanaan untuk meningkatkan kemampuan berolahraga yang berisikan teori dan praktek, metode dan aturan pelaksanaan sesuai dengan tujuan dan sasaran yang ingin dicapai. Berdasarkan berbagai macam pengertian latihan di atas maka dalam 
penelitian ini bahwa istilah latihan yang sesuai adalah pengertian dari training.

Selain pendapat di atas, ada beberapa pendapat para ahli, di antaranya McMorris \& Hale (2006, p.97) juga mengemukakan hal yang berkaitan dengan kata practice yakni: Practice is essential if learning is to take place. To the congnitivists, practice follows instruction. It is the keyfactor in the intermediate and autonomous stages of fits and posner, would see it as being when we move from declarative knowledge (knowing what to do) to procedural knowledge (developing the ability to perform the task). Maksud dari pernyataan McMorris \& Hale, praktik adalah hal yang penting untuk mengembangkan pengetahuan dengan mengikuti instruksi-instruksi yang diberikan yang akan mengubah pengetahuan deklaratif (mengetahui apa yang harus dilakukan) hingga pengetahuan prosedural (mengembangkan kemampuan untuk melakukan tugas). Menurut Drake $(2009$, p.51) ada beberapa hal penting di dalam practice yang baik, yakni: Offers areas of provision on a continuous basis to enable children to develop ideas and understanding over time. Encourage children as independent learners and thinkers within the environment, organizing provision to promote self selection and decision making.

Maksud dari pernyataan Drake, dengan practice secara terus-menerus maka akan memungkinkan anak untuk mengembangkan ide dan pemahaman dari waktu ke waktu. Practice juga mendorong anak-anak untuk dapat mandiri dan mengembangkan kreativitas. Berikut selain pendapat McMorris \& Hale tersebut yang mengemukakan hal yang berkaitan dengan practice, Birch, Maclaren, \& George (2005, p.1) juga mengemukakan latihan yang berasal dari kata exercise yakni: "exercise is defined as repetitive physical activity or movement aimed at improving or maintaining fitness or health". Maksud dari pernyataan Birch, Maclaren, \& George, latihan didefinisikan sebagai aktivitas fisik yang berulang atau gerakan yang bertujuan untuk meningkatkan atau mempertahankan kebugaran maupun kesehatan. Lebih lanjut Gordon (2009, p.90) mengemukakan: "training can be viewed as a very powerful stimulus which evokes a response in the body, the result of which is adaptation". Maksud dari pernyataan Gordon, latihan dapat dilihat sebagai stimulus yang sangat kuat yang dapat membangkitkan respon dalam tubuh, yang hasilnya adalah adaptasi.
Berdasarkan pengertian latihan tersebut, jelaslah bahwa latihan sangat berperan penting bagi atlet untuk mencapai prestasi, dengan adanya program latihan yang disusun dan di implementasikan secara kontinyu, maka atlet akan terbiasa beradaptasi serta meningkatkan kualitas fisik maupun psikis. Pada prinsipnya latihan merupakan suatu proses perubahan ke arah yang lebih baik, yaitu untuk meningkatkan: kualitas fisik, kemampuan fungsional peralatan tubuh, dan kualitas psikis anak latih. Dalam olahraga prestasi proses tersebut akan berhasil apabila ada kerja sama antara pelatih yang berpengalaman dan berpengetahuan dengan ilmu olahraga yang benar-benar menekuni bidang kepelatihan (Sukadiyanto, 2010, p.1).

Dalam olahraga beladiri judo diperlukan latihan yang baik dan teratur untuk mencapai hasil yang maksimum dan menuju prestasi yang lebih baik. Selain itu juga ada beberapa faktor yang harus dikuasai oleh setiap pejudo atau judoka agar mampu mencapai prestasi yang tinggi. Menurut Sukadiyanto (2010, p.5) kualitas latihan ditentukan terutama oleh keadaan dan kemampuan pelatih serta olahragawan, keduanya harus memiliki kemampuan, kemauan, dan komitmen yang tinggi untuk meraih hasil yang baik.

Pada Unit Kegiatan Mahasiswa (UKM) Judo di Universitas Negeri Yogyakarta dan Judo Sleman para pejudo atau atlet masih kurang sekali menerima bentuk-bentuk variasi latihan judo. Latihan yang diberikan pelatih hanya bersifat monoton. Karena program latihan yang monoton hal ini berdampak juga pada pejudo saat randori/bertanding pejudo tidak berani untuk mengambil teknik atau mengeluarkan teknik untuk membanting lawan. Selain itu program latihan yang diberikan oleh pelatih kurang sistematis, pelatih juga tidak melihat karakteristik atlet.

Berdasarkan hasil observasi dalam kejuaraan internasional, nasional dan kejuaraan daerah setiap pejudo memiliki jurus atau teknik andalan dalam setiap pertandingan, teknikteknik yang dipakai pada saat bertanding sebagian besar adalah teknik osoto gari. ippon seoi nage, tai otoshi, uchi mata. Teknik ini paling banyak dipakai karena teknik ini merupakan teknik yang efektif dan efisien dalam pertandingan atau randori. Hal ini berbanding terbalik pada pejudo-pejudo yang berada di Yogyakarta khususnya Kabupaten Sleman, pejudo berlatih teknik bantingan semaunya 


\section{Jurnal Keolahragaan 4 (1), April 2016 - 51}

Suwarli

sendiri tanpa melihat dan memperhatikan teknik yang efektif dan efesien serta memiliki karakter sesuai dengan keadaan fisik maupun postur bagi setiap pejudo, hal ini juga bisa dilihat dari hasil PON Riau 2012 cabor judo hanya bisa menyumbangkan satu medali perunggu. Begitu juga prestasi atlet yang berlatih di UKM Judo UNY dan Club Judo Sleman, pada perhelatan Kejuaraan Nasional Mahasiswa 2013 yang dilaksanakan di Yogyakarta. Seharusnya bertindak sebagai tuan rumah lebih diuntungkan serta mampu keluar sebagai juara umum karena atlet sudah terbiasa dengan atmosfer di daerah sendiri, tetapi kenyataannya hanya mampu meyumbangkan medali satu emas, dua perak, dan tiga perunggu (PB PJSI Yogyakarta, 2013). Selain permasalahan di atas setelah peneliti menelusuri lebih lanjut, mengapa prestasi cabang olahraga judo di Yogyakarta sangat sulit tercapai, hal ini dikarenakan minimnya kompetisi atau kejuaraan daerah yang sangat jarang dilakukan oleh PB PJSI Yogyakarta, apabila kejuaraan daerah sering diselenggarakan sehingga terjadi persaingan yang dapat menimbulkan semangat atlet untuk berprestasi akan semakin tinggi.

Berangkat dari minimnya prestasi atlet judo di daerah Yogyakarta inilah peneliti bermaksud untuk mengembangkan teknik atau memberikan metode latihan serta program yang sedikit berbeda dari yang diberikan oleh pelatih bahkan bisa juga memadukan atau kolaborasi program yang dimiliki pelatih dengan program yang dipersiapkan oleh peneliti. Dengan memadukan atau berkolaborasi program latihan antara pelatih dan peneliti ini diharapkan dapat meningkatkan teknik-teknik bantingan pada atlet UKM Judo Universitas Negeri Yogyakarta dan atlet yang berlatih di club Judo Sleman.

Program latihan judo terdapat istilah uchikomi, uchikomi adalah latihan memasukan atau membiasakan gerakan salah satu tehnik bantingan yang dilakukan secara berulangulang. Pada UKM Judo Universitas Negeri Yogyakarta dan club Judo Sleman uchikomi kurang sekali dilakukan oleh pejudo baik itu repetisinya dan variasi-variasinya sehingga teknik yang diandalkan kurang berkembang. Uchikomi yang sering dilakukan oleh pejudo hanya uchikomi di tempat.

Berdasarkan masalah tersebut maka, yang perlu ditingkatkan adalah bentuk-bentuk latihan yang lebih bervariasi terutama pada uchikomi pejudo. Salah satu uchikomi yang baik adalah uchikomi dengan menggunakan karet ban sepeda, dengan menggunakan karet ban sepeda pada saat melakukan uchikomi ini akan lebih membantu karena ban sepeda berasal dari karet yang bekerja dengan sistem pegas sehingga menimbulkan tarikan pada saat melakukan uchikomi, selain itu juga karet ban sepeda harganya ekonomis, serta dengan uchikomi menggunakan karet ban sepeda ini juga dapat melatih dua komponen pilar latihan yaitu dapat melatih tehnik sekaligus fisik atlet, uchikomi yang bervariasi lain adalah uchikomi jalan. Uchikomi jalan ini bisa membantu pejudo untuk belajar kecepatan serta timing yang tepat untuk membanting lawan. Untuk itu diharapkan dengan menggunakan latihan variasi uchikomi dengan menggunakan karet ban sepeda dan uchikomi jalan dapat meningkatkan hasil bantingan UKM Judo Universitas Negeri Yogyakarta dan club Judo Sleman.

Keberhasilan dalam melakukan teknik bantingan dipengaruhi faktor pejudo itu sendiri, perbedaan kemampuan terutama terjadi karena kualitas fisik atau biomotor yang berbeda. Salah satu komponen biomotor yang memiliki peran dalam melakukan bantingan judo yang benar adalah flexibility. Menurut Harsono (2000, p.15) kelentukan adalah kemampuan untuk bergerak dalam ruang gerak sendi. Kemampuan Perbedaan flexibility dapat dibedakan menjadi dua yaitu flexibility tinggi dan flexibility rendah. Perbedaan flexibility yang ada pada setiap atlet harus menjadi pertimbangan sebagai suatu faktor yang menentukan dalam menentukan hasil bantingan.

Dalam penelitian ini uchikomi yang akan diterapkan adalah uchikomi menggunakan karet ban sepeda dan uchikomi jalan, teknik yang akan dilatih dengan menggunakan karet ban sepeda dan uchikomi jalan adalah teknik osoto gari. Ippon seoi nage, tai otoshi, dan uchi mata hal ini sesuai dengan hasil observasi dalam kejuaraan baik itu tingkat internasional maupun nasional serta kejuaraan daerah ke empat teknik inilah yang sering dipakai dalam pertandingan judo.

Kelebihan uchikomi menggunakan karet ban sepeda adalah (1) Karena ban sepeda terbuat dari karet sehingga pada saat melakukan uchikomi karet bekerja seperti pegas yang mampu menarik kembali pada saat melakukan uchikomi, (2) Uchikomi dengan karet ban sepeda melatih komponen fisik yang menggabungkan dua komponen fisik sekaligus yaitu kekuatan dan kecepatan atau sering disebut dengan power, (3) Uchikomi karet dapat dilakukan secara mandiri, (4) Dari segi ekonomis uchikomi 
karet mudah dibeli karena harganya yang tidak terlalu mahal. Sedangkan kelemahan uchikomi jalan adalah (1) Bagi atlet yang memiliki flexibility rendah akan mengalami kesulitan dalam melakukan uchikomi, karena karet ban sepeda bersifat seperti pegas sehingga menimbulkan tarikan kembali ketika ditarik, (2) Uchikomi karet terlalu tergantung pada satu titik, (3) Uchikomi karet tidak membiasakan atlet berhadapan langsung dengan individu lain sehingga mengalami perbedaan ketika atlet dirandorikan atau dipertandingkan.

Kelebihan uchikomi jalan adalah (1) Uchikomi jalan akan membiasakan pejudo untuk membanting lawan secara langsung pada saat randori, (2) Uchikomi jalan akan membiasakan ketepatan atau timing pejudo pada saat randori, (3) Uchikomi jalan bisa diterapkan program variasi latihan baik repetisi serta kecepatan, (4) Di sisi lain uchikomi jalan juga pada saat bergantian pasangan akan menjadi variasi bagi pejudo pada saat uchikomi baik itu sesuai dengan berat badan, tinggi dan rendahnya pasangan sehingga pejudo pada saat randori atau bertanding akan terbiasa dengan ukuran baik lawan yang berukuran tinggi atau rendah. Sedangkan kelemahan uchikomi jalan adalah (1) Uchikomi jalan terlalu memudahkan atlet terkadang pasangan uke (lawan yang dibanting) membantu tori (yang membanting) dalam melakukan uchikomi, (2) Uchikomi jalan tidak bisa dilakukan secara mandiri karena memerlukan bantuan dari pasangan, (3) Uchikomi jalan terlalu memakan tempat untuk berlatih sehingga memungkinkan jeda yang terlalu lama bagi atlet pasangan lain untuk bergantian melakukan Uchikomi.

Perbedaan uchikomi dengan karet ban sepeda dan uchikomi jalan adalah (1) Uchikomi dengan karet ban sepeda bisa dilakukan dengan mandiri sedangkan pada uchikomi jalan harus dilakukan dengan berpasangan, (2) Uchikomi dengan karet ban sepeda akan mudah dilakukan pada atlet yang memiliki flexibility tinggi sedangkan pada uchikomi jalan akan mudah bagi atlet yang memiliki flexibility rendah, (3) Uchikomi dengan karet ban sepeda hanya terfokus pada satu titik sedangkan pada uchikomi jalan akan membiasakan atlet untuk bergerak sesuai atau identik dengan pertandingan atau randori, (4) Uchikomi dengan karet ban sepeda tidak membutuhkan tempat yang luas sedangkan pada uchikomi jalan membutuhkan tempat yang cukup luas.
Komponen biomotor fleksibilitas merupakan salah satu unsur yang penting dalam rangka pembinaan olahraga. Tingkat kualitas fleksibilitas sesorang akan berpengaruh terhadap komponen-komponen biomotor yang lainnya (Sukadiyanto, 2010, p.206). Keuntungan para atlet yang memiliki kualitas fleksibilitas yang baik, antara lain; (1) akan memudahkan atlet dalam menampilkan berbagai kemampuan gerak dan keterampilan, (2) menghindarkan diri dari kemungkinan akan terjadinya atau mendapatkan cidera pada saat melakukan aktivitas fisik, (3) memungkinkan atlet untuk dapat melakukan gerak yang ekstrim, (4) memperlancar aliran darah sehingga sampai pada serabut otot. Oleh karena itu fleksibilitas merupakan unsur dasar yang juga harus ditingkatkan, terutama pada atlet yang masih muda usianya. Penelitian ini juga tidak melupakan bagian komponen fisik yang lain karena dalam olahraga judo semua komponen fisik berpengaruh dalam setiap gerakan olahraga judo seperti kekuatan, kecepatan, daya tahan, power, kelincahan, keseimbangan serta komponen fisik yang lain.

Berdasarkan teori tersebut dalam penelitian ini komponen biomotor yang digunakan sebagai variabel atribut adalah fleksibilitas. Fleksibilitas digunakan dalam penelitian ini dikarenakan fleksibilitas merupakan salah satu faktor yang berpengaruh terhadap hasil bantingan judo yang baik. Menurut Achmad (2013, p.45) fleksibilitas sangat dibutuhkan dalam melakukan bantingan judo yang baik karena hampir semua tehnik bantingan judo berporos pada komponen biomotor fleksibilitas. Selain itu syarat dalam penelitian faktorial yang mana variabel atribut harus memiliki peran atau pengaruh terhadap variabel independen.

\section{METODE}

Metode yang digunakan dalam penelitian ini adalah metode eksperimen. Sebagaimana dikemukakan oleh Surahmad (2003, p.149) sebagai berikut: Dalam arti kata yang luas bereksperimen adalah mengadakan kegiatan percobaan untuk melihat suatu hasil. Penelitian ini adalah penelitian eksperimen yang bertujuan untuk membandingkan dua perlakuan yang berbeda pada subjek penelitian. Metode penelitian yang digunakan dalam penelitian ini adalah menggunakan rancangan faktorial $2 \times 2$, yaitu suatu eksperimen faktorial yang menyangkut dua faktor. Masing-masing faktor terdiri atas dua buah taraf, dengan menggunakan tes awal 
(pretest) dan tes akhir (posttest). Menurut Sudjana (2002, p.148) eksperimen faktorial adalah eksperimen yang hampir atau semua taraf sebuah faktor dikombinasikan atau disilangkan dengan semua taraf tiap faktor lainnya yang ada dalam eksperimen. Data penelitian ini disusun dalam kerangka desain penelitian dengan rancangan faktorial $2 \times 2$ sebagai berikut:

Tabel 1. Kerangka Desain Penelitian

\begin{tabular}{ccc}
\hline $\begin{array}{c}\text { Variabel } \\
\text { Manipulatif } \\
\text { Variabel Atributif }\end{array}$ & $\begin{array}{c}\text { Uchikomi } \\
\text { Dengan Karet } \\
\text { Ban Sepeda (a1) }\end{array}$ & $\begin{array}{c}\text { Uchikomi } \\
\text { Jalan } \\
\text { (a2) }\end{array}$ \\
\hline $\begin{array}{c}\text { Flexibility Tinggi } \\
\text { (b1) }\end{array}$ & a1b1 & a2b1 \\
$\begin{array}{c}\text { Flexibility Rendah } \\
\text { (b2) }\end{array}$ & a1b2 & a2b2 \\
\hline
\end{tabular}

Keterangan:

a1b1: Kelompok pejudo yang memiliki flexibility tinggi dilatih mengunakan metode uchikomi dengan karet ban sepeda.

a2b1: Kelompok pejudo yang memiliki flexibility tinggi dilatih mengunakan metode uchikomi jalan.

a1b2: Kelompok pejudo yang memiliki fleksibilitiy rendah dilatih mengunakan metode uchikomi dengan karet ban sepeda.

a2b2: Kelompok pejudo yang memiliki flexibility tinggi dilatih mengunakan metode uchikomi jalan.

\section{Tempat dan Waktu Penelitian}

Penelitian ini akan dilaksanakan di Dojo Universitas Negeri Yogyakarta dan Dojo Club Judo Sleman. Penelitian lapangan ini akan dilakukan selama tujuh minggu. Pemberian treatment akan dilakukan selama tujuh minggu dengan frekuensi pertemuan tiga kali seminggu. Hal ini sesuai dengan pendapat Bompa \& Haff (2009, p.207) maksudnya adalah agar tubuh beradaptasi dengan beban latihan yang diterima.

\section{Populasi dan Sampel Penelitian}

Populasi dalam suatu penelitian merupakan kumpulan individu atau objek yang mempunyai sifat-sifat umum. Menurut Sudjana (2002, p.6). "Populasi adalah totalitas semua nilai yang mungkin, hasil menghitung ataupun pengukuran kuantitatif kualitatif, megenai karakteristik tertentu dari semua anggota kumpulan lengkap dan jelas, yang dipelajari sifatsifatnya". Populasi yang digunakan dalam penelitian ini adalah seluruh pejudo yang berlatih di UKM Judo Universitas Negeri Yogyakarta dan Club Judo Sleman sebanyak 44 orang. Dalam suatu proses penelitian, tidak perlu seluruh populasi diteliti, akan tetapi dapat dilakukan terhadap sebagian dari jumlah populasi tersebut. Sebagaimana yang dikemukakan oleh Arikunto (2002, p.109) menjelaskan bahwa sampel adalah sebagian atau wakil dari populasi yang diteliti.

Cara pengambilan sampel tersebut yaitu sebelum eksperimen dilaksanakan, populasi sebanyak 44 pejudo dilakukan tes dan pengukuran flexibility yang diperoleh dengan instrumen sit and reach. Tes ini digunakan untuk mengetahui skor awal yang menunjukkan tingkat flexibility. Setelah data flexibility terkumpul, langkah pertama dalam analisis adalah untuk mengidentifikasikan kelompok atas dan bawah dengan menggunakan skor tes keseluruhan.

Langkah untuk menganalisis data tersebut adalah sebagai berikut: (1) mengatur tes dalam rangka menentukan skor tinggi dan skor rendah, (2) menentukan $27 \%$ skor tinggi dan $27 \%$ skor rendah dengan menempatkan dalam satu kelompok sama. Kelompok-kelompok ini disebut kelompok atas dan kelompok bawah, dengan demikian $27 \%$ kelompok atas dan $27 \%$ kelompok bawah dianggap yang terbaik untuk memaksimalkan perbedaan antara dua kelompok (Miller, 2002, p.68).

Pengelompokan dilakukan dengan cara data flexibility yang telah diperoleh dirangking terlebih dahulu (dibuat dari peringkat dari yang tinggi ke yang rendah), sampel diambil dari pejudo yang memiliki flexibility tinggi yaitu $27 \%$ peringkat atas dan pejudo yang memiliki flexibility rendah yaitu $27 \%$ peringkat bawah dari seluruh data flexibility yang telah dirangking. Berdasarkan hal tersebut didapat 12 pejudo yang memiliki flexibility tinggi dan 12 pejudo yang memiliki flexibility rendah, kemudian masing-masing dibagi menjadi dua kelompok dengan cara diundi (random), yaitu 12 pejudo mendapat metode uchikomi dengan menggunakan karet ban sepeda dan 12 pejudo mendapat metode uchikomi jalan yang artinya dari dua kelompok tersebut menjadi empat kelompok sel.

Pembagian kelompok dengan cara ini akan lebih objektif bagi semua subjek penelitian. Hal ini didasarkan atas kesempatan yang sama bagi semua objek untuk masuk ke dalam tiap kelompok. Setelah terbagi menjadi empat kelompok, selanjutnya setiap kelompok flexibility tinggi dan rendah melakukan pretest randori dengan melihat hasil bantingan sebelum 


\section{Jurnal Keolahragaan 4 (1), April 2016 - 54}

Suwarli

dilakukan eksperimen dengan pemberian perlakuan (treatment).

\section{Variabel Penelitian}

Variabel bebas (Independent) Variabel bebas manipulatif yaitu metode latihan yang terdiri atas dua metode, antara lain: (1) Metode uchikomi dengan karet ban sepeda, dan (2) Metode uchikomi jalan. Variabel bebas atributif (yang dikendalikan) dalam penelitian ini, terdiri: (1) Flexibility tinggi, dan (2) Flexibility rendah. Variabel terikat dalam penelitian ini yaitu ketepatan hasil bantingan.

\section{Teknik dan Instrumen Pengumpulan Data}

Menurut Sugiyono (2012, p.148). "Instrumen adalah alat ukur yang digunakan dalam penelitian". Data flexibility Teknik pengumpulan data diperoleh dengan tes menggunakan instrumen Sit and Reach. Sedangkan Teknik pengumpulan data tentang hasil bantingan diperoleh dengan tes praktik masing-masing atlet dirandorikan atau dipertandingkan selama 3 menit lalu dinilai oleh wasit judo dengan 4 tingkatan nilai yaitu koka dengan nilai 1 (bantingan ini didapat apabila hasil bantingan hanya uke jatuh pada posisi duduk). Yuko dengan nilai 2 (bantingan ini didapat apabila hasil bantingan hanya uke jatuh pada posisi miring). Waza-ari dengan nilai 3 (bantingan ini didapat apabila hasil bantingan hanya uke jatuh pada posisi hampir melayang seluruh tubuh dan punggung serta bahu semua hampir menempel dimatras). Ippon dengan nilai 4 (bantingan ini didapat apabila hasil bantingan uke jatuh pada posisi seluruh tubuh melayang dan punggung serta bahu menempel dimatras atau nilai mutlak).

\section{Validitas dan Reliabilitas Instrumen}

Validitas adalah sejauh mana ketepatan dan kecermatan suatu alat ukur dalam melakukan fungsi ukurannya atau memberikan hasil ukur yang sesuai dengan maksud dilakukannya pengukuran tersebut. Menurut Muhidin \& Abdurahman (2007, p.30) instrumen dinyatakan memiliki validitas apabila instrumen tersebut telah dirancang dengan baik dan mengikuti teori dan ketentuan yang ada. Validitas hasil bantingan sebesar 0,855 dan validitas untuk flexibility sebesar 0,978. Reliabilitas adalah sejauh mana hasil pengukuran dapat menunjukkan hasil relatif sama dalam beberapa kali pengukuran terhadap kelompok subjek yang sama
(Muhidin \& Abdurahman, 2007, p.37). Reliabilitas untuk hasil bantingan sebesar 0,917 dan flexibility sebesar 0,987.

\section{Teknik Analisis Data}

Teknik analisis data yang digunakan dalam penelitian ini dengan menggunakan SPSS 20 yaitu Analisis Varian (ANAVA) dua jalur pada taraf signifikansi $\alpha=0,05$. Untuk memenuhi asumsi ANAVA maka dilakukan uji normalitas dengan Kolmogorov Smirnow dan homogenitas dengan uji Levene Test. Untuk menguji hipotesis dilakukan dengan menggunakan ANOVA dua jalur dan apabila terbukti terdapat interaksi maka akan dilakukan uji lanjutan yaitu uji pairwise comparisons yaitu dengan menggunakan program software SPSS version 20.0 for windows dengan taraf signifikansi $5 \%$ atau 0,05 .

\section{HASIL DAN PEMBAHASAN}

\section{Hasil Penelitian}

Hasil yang diperoleh dari penelitian berupa data yang merupakan gambaran umum tentang masing-masing variabel yang terkait dalam penelitian. Melalui gambaran umum ini akan nampak kondisi awal dan kondisi akhir dari setiap variabel yang diteliti dengan melakukan pengolahan data setelah data berhasil dikumpulkan selama periode latihan yang telah ditentukan.

Pada Tabel 2 diperoleh data: (1) untuk kelompok A1B1 pada tes awal diperoleh ratarata sebesar 13,5 setelah dilakukan perlakuan dengan uchikomi karet ban sepeda didapat ratarata meningkat menjadi 23,5 sehingga peningkatan pada kelompok A1B1 sebesar 10, (2) untuk kelompok A1B2 pada tes awal diperoleh rata-rata sebesar 9,67 setelah dilakukan perlakuan dengan uchikomi karet ban sepeda didapat rata-rata meningkat menjadi 12 sehingga peningkatan pada kelompok A1B2 sebesar 2,33, (3) untuk kelompok A2B1 pada tes awal diperoleh rata-rata sebesar 13,85 setelah dilakukan perlakuan dengan uchikomi jalan didapat ratarata meningkat menjadi 19,83 sehingga peningkatan pada kelompok A2B1 sebesar 6, (4) untuk kelompok A2B2 pada tes awal diperoleh rata-rata sebesar 9 setelah dilakukan perlakuan dengan uchikomi jalan didapat rata-rata meningkat menjadi 20,5 sehingga peningkatan pada kelompok A2B1 sebesar 11,5. 
Jurnal Keolahragaan 4 (1), April 2016 - 55

Suwarli

Tabel 2. Deskripsi Data Hasil Bantingan Judo tiap Kelompok Berdasarkan Penggunaan Metode Latihan Uchikomi dengan Karet Ban Sepeda dan Uchikomi Jalan dan Flexibility

\begin{tabular}{cccccc}
\hline \multirow{2}{*}{ Perlakuan } & $\begin{array}{c}\text { Tingkat } \\
\text { Flexibility }\end{array}$ & Statistik & $\begin{array}{c}\text { Hasil Tes } \\
\text { Awal }\end{array}$ & $\begin{array}{c}\text { Hasil Tes } \\
\text { Akhir }\end{array}$ & Peningkatan \\
\hline & & Jumlah & 81 & 141.00 & 60 \\
Metode Latihan Uchikomi dengan & Tinggi & Rerata & 13.5 & 23.50 & 10.00 \\
kare Ban Sepeda & & SD & 2.88 & 2.74 & 2.10 \\
& & Jumlah & 58 & 72 & 14 \\
& Rendah & Rerata & 9.67 & 12.00 & 2.33 \\
& & SD & 2.50 & 1.41 & 2.25 \\
Metode Latihan Uchikomi Jalan & & Jumlah & 83 & 119 & 36 \\
& Tinggi & Rerata & 13.83 & 19.83 & 6.00 \\
& & SD & 3.54 & 3.87 & 3.10 \\
& & Jumlah & 54.00 & 123.00 & 69.00 \\
& Rendah & Rerata & 9.00 & 20.50 & 11.50 \\
& & SD & 2.83 & 2.17 & 0.84 \\
\hline
\end{tabular}

Hal yang menarik dari tabel nilai-nilai di atas adalah jika antara kelompok yang dilatih metode latihan uchikomi dengan menggunakan karet ban sepeda dan uchikomi jalan dibandingkan, maka diketahui bahwa kelompok perlakuan latihan uchikomi dengan menggunakan karet ban sepeda pada kelompok flexibility tinggi (A1B1) sebesar 10,00 dan metode latihan uchikomi dengan menggunakan karet ban sepeda kelompok flexibility rendah (A1B2) sebesar 2,33, sedangkan pada uchikomi jalan kelompok flexibility tinggi (A2B1) sebesar 6,00 dan uchikomi jalan kelompok flexibility rendah (A2B2) sebesar 11,50. Jika diperhatikan lebih rinci bawa keempat kelompok perlakuan yang memiliki peningkatan yang besar adalah (1) pada kelompok metode latihan uchikomi jalan pada flexibility rendah (A2B1), (2) pada kelompok uchikomi dengan menggunakan karet ban sepeda pada flexibility tinggi (A1B1), (3) pada kelompok uchikomi jalan pada flexibility tinggi (A2B1), dan (4) pada kelompok metode latihan uchikomi dengan menggunakan karet ban sepeda pada flexibility rendah (A1B2).

\section{Uji Normalitas Data}

Uji normalitas data dalam penelitian ini digunakan metode Kolmogorov Smirnov. Hasil uji normalitas data yang dilakukan pada tiap kelompok analisis dilakukan dengan program software SPSS version 20.0 for windows dengan taraf signifikansi 5\% atau 0,05.

Berdasarkan analisis statistik uji normalitas yang telah dilakukan dengan menggunakan uji $Z$ Kolmogorov Smirnov, pada data hasil bantingan tes awal didapat dari hasil uji normalitas data yang dilakukan pada metode uchikomi menggunakan karet ban sepeda yang memiliki flexibility tinggi (A1B1) terdapat tingkat signifikan sebesar 0,972 ini berarti $p>0,05$, yang berarti data berdistribusi normal. Pada metode uchikomi menggunakan karet ban sepeda yang memiliki flexibility rendah (A1B2) terdapat tingkat signifikan sebesar 0,966 , ini berarti $p$ > 0,05 , yang berarti data berdistribusi normal. Sedangkan pada metode uchikomi jalan yang memiliki flexibility tinggi (A2B1) terdapat tingkat signifikan sebesar 0,978 ini berarti $\mathrm{p}>0,05$, yang berarti bahwa data berdistribusi normal. Selanjutnya pada metode uchikomi jalan yang memiliki flexibility rendah (A2B2) terdapat tingkat signifikan sebesar 0,976 ini berarti $\mathrm{p}>$ 0,05 , yang berarti bahwa data berdistribusi normal. Hal ini berarti data pada tes awal setiap kelompok merupakan statistik parametrik.

Berdasarkan analisis statistik uji normalitas pada hasil bantingan judo tes akhir yang telah dilakukan dengan menggunakan uji $Z$ Kolmogorov Smirnov, pada data hasil bantingan tes awal didapat dari hasil uji normalitas data yang dilakukan pada metode uchikomi menggunakan karet ban sepeda yang memiliki flexibility tinggi (A1B1) terdapat tingkat signifikan sebesar 0,883 ini berarti $p>0,05$, yang berarti bahwa data berdistribusi normal. Pada metode uchikomi menggunakan karet ban sepeda yang memiliki flexibility rendah (A1B2) terdapat tingkat signifikan sebesar 0,996 ini berarti $\mathrm{p}$ > 0,05 , yang berarti bahwa data berdistribusi normal. Sedangkan pada metode uchikomi jalan yang memiliki flexibility tinggi (A2B1) terdapat tingkat signifikan sebesar 0,714 ini berarti $p$ > 0,05 , yang berarti bahwa data berdistribusi normal. Selanjutnya pada metode uchikomi jalan yang memiliki flexibility rendah (A2B2) terdapat tingkat signifikan sebesar 0,820 ini 


\section{Jurnal Keolahragaan 4 (1), April 2016 - 56}

Suwarli

berarti $\mathrm{p}>0,05$, yang berarti bahwa data berdistribusi normal. Hal ini berarti data pada tes akhir setiap kelompok merupakan statistik parametrik.

\section{Uji Homogenitas}

Uji homogenitas dilakukan untuk menguji persamaan beberapa sampel yaitu homogen atau tidak. Uji homogenitas dimaksudkan menguji kesamaan varian antara kelompok 1 dan kelompok 2. Uji homogenitas pada penelitian ini adalah uji Levene Test.

Berdasarkan analisis statistik uji homogenitas yang telah dilakukan dengan menggunakan uji Levene Test. Diperoleh nilai signifikansi sebesar 0,702 > 0,05. Hal ini berarti dalam kelompok data memiliki varian yang homogen. Hal ini berarti data pada tes awal dan akhir setiap kelompok merupakan statistik parametrik.

\section{Pengujian Hipotesis}

Pengujian hipotesis penelitian dilakukan berdasarkan hasil analisis data dan interpretasi analisis varian dua jalur. Analisis varian dua jalur digunakan untuk menguji pengaruh utama (main effect) antara variabel bebas metode latihan dan variable atribut flexibility (simple effect) terhadap hasil bantingan pada pejudo UKM UNY dan pejudo Club Judo Sleman. Uji Pairwise Comparisons ditempuh sebagai langkahlangkah uji rata-rata setelah Anava guna mengetahui secara terperinci rata-rata yang beda.

\section{Hipotesis I}

Hipotesis yang dinyatakan bahwa: Ada perbedaan pengaruh antara metode uchikomi dengan menggunakan karet ban sepeda dan uchikomi jalan terhadap hasil bantingan pada UKM Judo Universitas Negeri Yogyakarta dan Club Judo Sleman. Berdasarkan dari nilai signifikansi Univariate Tests sebesar 0,04 $<0,05$ yang berarti bahwa lebih kecil dari taraf signifikan. Dengan demikian hipotesis I yang menyatakan ada perbedaan pengaruh antara metode uchikomi dengan menggunakan karet ban sepeda dan uchikomi jalan terhadap hasil bantingan judo yang baik, diterima. Dari analisis lanjutan diperoleh bahwa ternyata metode latihan uchikomi jalan memiliki peningkatan yang lebih baik dari pada metode latihan uchikomi dengan karet ban sepeda. Dengan demikian metode latihan uchikomi jalan lebih bagus dari pada metode latihan uchikomi karet pada masa sebelum retensi, sebagai hasil fase latihan

Hipotesis II

Hipotesis yang dinyatakan bahwa: Ada perbedaan peningkatan hasil bantingan antara atlet yang memiliki flexibility tinggi dan rendah. Berdasarkan dari nilai signifikansi Univariate Tests sebesar 0,00<0,05 yang berarti bahwa lebih kecil dari taraf signifikan. Dengan demikian hipotesis 2 yang menyatakan ada perbedaan peningkatan hasil bantingan judo yang baik antara atlet yang memiliki flexibility tinggi dan flexibility rendah, diterima. Dari analisis lanjutan diperoleh bahwa ternyata pejudo yang memiliki flexibility tinggi memiliki peningkatan yang lebih baik dari pada pejudo yang memiliki flexibility rendah, dengan rata-rata peningkatan masing-masing yaitu pejudo yang memiliki flexibility tinggi 21.667 dan pejudo yang memiliki flexibility rendah sebesar 16.250. Dengan demikian pejudo yang memiliki flexibility tinggi lebih bagus dari pada pejudo yang memiliki flexibility rendah pada masa sebelum retensi, sebagai hasil fase latihan.

\section{Hipotesis III}

Hipotesis yang dinyatakan bahwa: Ada interaksi antara metode uchikomi dan flexibility terhadap hasil bantingan judo yang baik pada UKM Judo Universitas Negeri Yogyakarta dan Club Judo Sleman. Berdasarkan hasil perhitungan Tests of Between-Subjects Effects didapat bahwa taraf signifikansi sebesar $0,00<$ 0,05 , hal ini menunjukkan bahwa tingkat signifikansi $5 \%$ ada pengaruh bersama antara metode latihan uchikomi dan flexibility terhadap hasil bantingan judo. Dengan demikian hipotesis 3 yang menyatakan bahwa ada interaksi antara metode uchikomi dan flexibility terhadap hasil bantingan judo yang baik pada UKM Judo Universitas Negeri Yogyakarta dan Club Judo Sleman, diterima.

Setelah teruji terdapat interaksi antara metode uchikomi dan flexibility terhadap hasil bantingan judo yang baik maka perlu dilakukan uji lanjut dengan menggunakan Pairwise Comparisons. Berikut kelompok yang terdapat perbedaan secara signifikan: (a) Jika uchikomi karet dengan flexibility tinggi dipasangkan dengan uchikomi karet dengan flexibility rendah terdapat perbedaan pengaruh yang signifikan. (b) Jika uchikomi karet dengan flexibility tinggi dipasangkan dengan uchikomi jalan flexibility tinggi terdapat perbedaan pengaruh yang signi- 
fikan. (c) Jika uchikomi karet dengan flexibility rendah dipasangkan dengan uchikomi jalan flexibility tinggi terdapat perbedaan pengaruh yang signifikan. (d) Jika uchikomi karet dengan flexibility rendah dipasangkan dengan uchikomi jalan flexibility rendah terdapat perbedaan pengaruh yang signifikan.

Sedangkan pasangan-pasangan lainnya dinyatakan tidak memiliki perbedaan pengaruh adalah: (a) Jika uchikomi karet dengan flexibility tinggi dipasangkan dengan uchikomi jalan flexibility rendah tidak terdapat perbedaan pengaruh yang signifikan. (b) Jika uchikomi jalan dengan flexibility tinggi dipasangkan dengan uchikomi jalan flexibility rendah tidak terdapat perbedaan pengaruh yang signifikan.

\section{Pembahasan}

Pembahasan hasil penelitian ini memberikan penafsiran yang lebih lanjut mengenai hasil-hasil analisis data yang telah dikemukakan. Berdasarkan pengujian hipotesis menghasilkan dua kelompok kesimpulan analisis yaitu: (1) ada perbedaan pengaruh yang bermakna antara faktor-faktor utama penelitian. (2) ada interaksi yang bermakna antara faktor-faktor utama dalam bentuk interaksi dua faktor. Kelompok kesimpulan analisis tersebut dapat dipaparkan lebih lanjut sebagai berikut:

Perbedaan Pengaruh antara Latihan Uchikomi

Karet dan Uchikomi Jalan terhadap Hasil Bantingan Judo

Berdasarkan pengujian hipotesis pertama ternyata ada perbedaan pengaruh yang nyata antara kelompok pejudo yang mendapatkan metode uchikomi karet yang diterapkan pada UKM Judo UNY dan uchikomi jalan yang diterapkan di Club Judo Sleman Yogyakarta. Pada kelompok pejudo yang dilatih dengan uchikomi jalan mempunyai peningkatan hasil bantingan judo lebih baik jika dibandingkan dengan pejudo yang di berikan uchikomi karet.

Uchikomi jalan apa bila ditinjau dari metode latihannya Uchikomi jalan memiliki beberapa fungsi seperti melatih timing dan kecepatan pada saat membanting hal ini sangat berguna bagi setiap pejudo karena pada saat randori (bertanding) timing dan kecepatan membanting sangat berperan dalam pertandingan. Uchikomi jalan bisa dilakukan dengan cara berpasangan. Selain itu uchikomi jalan bisa diterapkan program variasi latihan baik repetisi serta kecepatan dalam melakukan uchikomi sehingga dapat meningkatkan hasil bantingan pejudo. Selain itu juga uchikomi jalan juga selain dapat meningkatkan teknik bantingan juga dapat meningkatkan fisik atlet apabila bentuk latihan yang diberikan bervariasi seperti uchikomi dengan spedd atau uchikomi jalan dengan mengangkat $u k e$.

Uchikomi dengan karet ban sepeda merupakan salah satu bentuk variasi latihan dengan menggunakan karet ban sepeda pada saat melakukan uchikomi ini akan lebih membantu karena ban sepeda berasal dari karet yang bekerja dengan sistem pegas sehingga menimbulkan tarikan pada saat melakukan uchikomi, selain itu juga karet ban sepeda harganya ekonomis. Dari Uchikomi karet ini juga dapat melatih dua komponen pilar latihan yaitu dapat melatih tehnik sekaligus fisik atlet.

Jika dilihat dari kelebihan masing-masing metode uchikomi di atas memang Nampak bahwa uchikomi jalan memiliki sedikit kelebihan jika dibandingkan dengan uchikomi karet, hal ini karena uchikomi jalan bisa diterapkan pada semua atlet yang memiliki flexibility tinggi atau rendah dan uchikomi jalan dalam pelaksanaannya juga sudah identik dengan suasana pertandingan atau randori sehingga atlet sudah terbiasa ketika dipertandingkan, sedangkan pada uchikomi karet karena karet ban sepeda bekerja seperti sistem pegas maka bagi atlet yang memiliki flexibility tinggi akan mudah melakukan sedangkan bagi atlet yang memiliki flexibility rendah akan mengalami kesulitan.

Berdasarkan kajian tersebut, tampak bahwa metode uchikomi jalan lebih baik dari pada uchikomi karet. Dapat disimpulkan bahwa metode uchikomi jalan lebih baik jika dibandingkan dengan metode uchikomi karet terhadap hasil bantingan judo yang baik. Selanjutnya berdasarkan kajian teori dan hasil penelitian dapat disimpulkan bahwa unchikomi dengan karet ban sepeda lebih cocok bagi atlet senior dan uchikomi jalan akan lebih baik bila diterapkan untuk atlet junior.

Perbedaan Pengaruh antara Flexibility Tinggi dan Rendah terhadap Hasil Bantingan Judo

Flexibility memiliki peran penting terhadap hasil bantingan judo. Flexibility dalam hal ini di mana tingkat kualitas fleksibilitas seseorang akan berpengaruh terhadap komponenkomponen biomotor yang lainnya (Sukadiyanto, 2010, p.206). Keuntungan para atlet yang memiliki kualitas fleksibilitas yang baik, antara lain; (1) akan memudahkan atlet dalam menampilkan berbagai kemampuan 
gerak dan keterampilan, (2) menghindarkan diri dari kemungkinan akan terjadinya atau mendapatkan cidera pada saat melakukan aktivitas fisik, (3) memungkinkan atlet untuk dapat melakukan gerak yang ekstrim, (4) memperlancar aliran darah sehingga sampai pada serabut otot. Oleh karena itu fleksibilitas merupakan unsur dasar yang juga harus ditingkatkan, terutama pada atlet yang masih muda usianya.

Flexibility yang dimiliki oleh atlet tidaklah sama, ada yang tinggi dan ada yang rendah, dan ini tentunya akan mempengaruhi terhadap hasil bantingan judo. Bagi atlet yang memiliki Flexibility tinggi tentunya akan mudah melakukan gerakan uchikomi sehingga dalam membanting lawan akan maksimal sedangkan bagi atlet yang memiliki flexibility rendah akan mengalami kesulitan dalam melakukan uchikomi. Hasil penelitian bahwa flexibility tinggi lebih baik hasilnya jika dibandingkan dengan flexibility rendah, akan tetapi jika ditelusuri pada setiap kelompok bahwa flexibility rendah mengalami hasil yang baik ketika diberikan treatmen uchikomi jalan, hal ini dikarenakan uchikomi jalan lebih mambantu dan memudahkan atlet dalam melakukan uchikomi selain itu uchikomi jalan juga lebih indentik dengan suasana pertandingan, jadi meskipun atlet hanya memiliki flexibility rendah, hasil dalam penelitian ini akan tetap mendapatkan solusi sehingga semua atlet yang memiliki tingkatan flexibility baik tinggi atau rendah bisa meraih prestasi.

Interaksi antara Latihan Uchikomi Karet dan Uchikomi Jalan serta Flexibility Tinggi dan Rendah terhadap Hasil Bantingan Judo

Berdasarkan hasil yang telah dikemukakan pada hasil penelitian di atas bahwa terdapat interaksi yang berarti antara metode uchikomi dan flexibility terhadap hasil bantingan judo pada atlet UKM Judo UNY dan Club Judo Sleman. Dari tabel yang disajikan bentuk interaksi nampak bahwa faktor-faktor utama penelitian dalam bentuk dua faktor menunjukan interaksi yang signifikan. Dalam hasil penelitian ini interaksi yang memiliki arti bahwa setiap sel atau kelompok terdapat perbedaan pengaruh setiap kelompok yang dipasang-pasangkan.

Berdasarkan hasil penelitian yang didapat, (1) ternyata atlet yang memiliki flexibility rendah dilatih dengan uchikomi jalan mengalami peningkatan yang lebih besar, urutan ke dua (2) atlet yang memiliki flexibility tinggi dilatih dengan uchikomi karet, urutan ke tiga (3) atlet yang memiliki flexibility tinggi dengan uchikomi jalan, dan yang ke empat (4) flexibility rendah uchikomi karet. Keefektifan yang diterapkan untuk meningkatkan hasil bantingan judo tersebut, dipengaruhi oleh tinggi rendahnya flexibility yang dimiliki atlet.

Dari beberapa pembahasan di atas untuk mengoptimakan teknik bantingan judo atlet apabila didapat atlet tersebut memiliki flexibility rendah maka atlet tersebut lebih cocok dilatih dengan metode uchikomi jalan dan atlet yang memiliki flexibility tinggi lebih cocok dilatih dengan uchikomi karet. Mengapa uchikomi jalan lebih cocok untuk atlet yang memiliki flexibility rendah? Hal ini dikarenakan atlet yang memiliki flexibility rendah akan lebih terbantu karena uchikomi jalan bersifat pasangan sehingga atlet akan terbantu untuk melakukan uchikomi, selain itu uchikomi jalan juga dalam pelaksanaannya lebih identik dengan suasana atau keadaan dalam bertanding, sedangkan bagi atlet yang memiliki flexibility tinggi lebih cocok dengan metode uchikomi karet mengapa? Hal ini dikarenakan sifat dari uchikomi karet bersifat seperti gaya pegas yang dapt menimbulkan gaya tarikan kembali sehingga bagi atlet yang memiliki flexibility tinggi akan mudah melakukannya jika di bandingkan bagi atlet yang memiliki flexibility rendah. Selanjutnya berdasarkan kajian teori dan hasil penelitian dapat disimpulkan bahwa unchikomi dengan karet ban sepeda lebih cocok bagi atlet senior dan uchikomi jalan akan lebih baik bila diterapkan untuk atlet junior.

\section{SIMPULAN DAN SARAN}

\section{Simpulan}

Ada perbedaan pengaruh yang signifikan antara metode uchikomi dengan menggunakan karet ban sepeda dan uchikomi jalan terhadap hasil bantingan judo yang baik pada UKM Judo Universitas Negeri Yogyakarta dan Club Judo Sleman.

Ada perbedaan yang signifikan antara atlit yang memiliki flexibility tinggi dan rendah terhadap peningkatan hasil bantingan judo yang baik pada UKM Judo Universitas Negeri Yogyakarta dan Club Judo Sleman.

Ada interaksi antara metode uchikomi dan flexibility terhadap hasil bantingan judo yang baik pada UKM Judo Universitas Negeri Yogyakarta dan Club Judo Sleman. Interkasi ini berfungsi untuk mencari perbedaan hasil bantingan judo yang baik antar kelompok sel, berikut pasangan-pasangan yang memiliki 
perbedaan secara signifikan: (a) uchikomi karet dengan flexibility tinggi (A1B1) dipasangkan dengan uchikomi karet dengan flexibility rendah (A1B2), (b) uchikomi karet dengan flexibility tinggi (A1B1) dipasangkan dengan uchikomi jalan flexibility tinggi (A2B1), (c) uchikomi karet dengan flexibility rendah A1B2) dipasangkan dengan uchikomi jalan flexibility tinggi (A2B1), (d) karet dengan flexibility rendah (A1B2) dipasangkan dengan uchikomi jalan flexibility rendah (A2B2). Sedangkan untuk dua kelompok lainnya tidak terdapat perbedaan yaitu: uchikomi karet dengan flexibility tinggi (A1B1) dipasangkan dengan uchikomi jalan flexibility rendah A2B2), dan uchikomi jalan dengan flexibility tinggi (A2B1) dipasangkan dengan uchikomi jalan flexibility rendah (A2B2).

\section{Saran}

Latihan uchikomi jalan memiliki pengaruh yang lebih baik dalam meningkatkan hasil bantingan judo, sehingga pelatih atau Pembina olahraga sebaiknya memilih latihan uchikomi jalan dalam upaya meningkatkan hasil bantingan judo.

Latihan uchikomi dengan karet ban sepeda dan uchikomi jalan perlu memperhatikan faktor flexibility serta prasarana dan sarana yang tersedia dalam meningkatkan hasil bantingan judo. Dalam upaya meningkatkan hasil bantingan judo, atlet yang memiliki flexibility tinggi akan lebih tepat dan efektif, jika dilatih dengan uchikomi karet.

Program latihan uchikomi jalan akan lebih tepat jika diberikan pada atlit yang memiliki flexibility rendah, dalam upaya meningkatkan hasil bantingan judo. Pelatih atau Pembina olahraga disarankan merancang program latihan yang tepat dan terencana sesuai dengan cabang olahraga masing-masing, mengingat kebutuhan hasil bantingan setiap cabang olahraga berbedabeda dan belum tentu suatu metode latihan sesuai atau cocok bagi semua kelompok.

\section{DAFTAR PUSTAKA}

Achmad, A.K.A. (2013). Dasar-dasar lengkap teknik judo untuk pelajar. Jakarta: PT Cipta Prima.

Arikunto, S. (2002). Prosedur penelitian suatu pendekatan praktik. Jakarta: PT Rineka Cipta.
Blais, L., Trilles, F., \& Lacouture P. (2007). Validation of a specific machine to the strength training of judokas. J Strength Cond Res: Journal Sport Of Therapy: 409-12.

Bompa, T. O., \& Haff, G.G. (2009). Theory and metodology of training. Iowa: Kendall Hunt Publishing Company.

Miller, D.K. (2002). Measurement by the physical educator why and how. New York: McGraw-Hill Education.

Muhidin, S.A., \& Abdurahman, M. (2007). Analisis regresi, dan jalur dalam penelitian. Bandung: CV Pestaka Setia.

Drake, J. (2009). Planning for children's play and learning. New York: Routledge Taylor \& Francis Group.

Elias, D. (2000). Judo olahragaku semangatku. Jakarta: PB-PJSI.

Gordon, D. (2009). Coaching science. London: SAGE.

Harsono. (2000). Coaching dan aspek-aspek psikologis dalam coaching. Jakarta: Tambak Kusuma.

Inokuma, I., \& Sato, N. (2001). Best judo. Tokyo: Kodansha International.

McMorris, T., \& Hale, T. (2006). Coaching science (Theory into practice). Chichester: John Wiley \& Sons Ltd.

PB PJSI Yogyakarta. (2013). Pengurus besar persatuan judo seluruh Indonesia Yogyakarta. Yogyakarta.

Sudjana. (2002). Desain dan analisis eksperimen. Bandung: Tarsito.

Sugiyono. (2012). Metode penelitian pendidikan. Bandung: Alfabeta

Sukadiyanto. (2010). Teori dan metodologi melatih fisik petenis. Yogyakarta: Fakultas Ilmu Keolahragaan UNY. Tidak diterbitkan.

Weinberg, R.S. \& Gould, D. (2007). Foundation of sport and exercises psychology. Miami: Human Kinetics. 